\section{Pruning Severity Affects Yield, Berry Weight, and Hand Harvest Efficiency of Highbush Blueberry}

\author{
Bernadine Strik $^{1}$ and Gil Buller ${ }^{2}$ \\ Department of Horticulture, Oregon State University, 4017 ALS, Corvallis, \\ OR $97331-7304$
}

\section{Edward Hellman ${ }^{3}$ \\ Texas A\&M University, Agricultural Research and Extension Center, Rt. 3, Box 219, Lubbock, TX 79401-9757}

Additional index words. Vaccinium corymbosum, dry weight, growth, partitioning, canopy, harvesting

\begin{abstract}
The following pruning treatments were studied in mature 'Bluecrop' (1996-2000) and 'Berkeley' (1996-98) plants: 1) "conventional” pruning with removal of unproductive canes, thinning of 1-year-old shoots at the base of the bush, and removal of any unproductive wood or thinning of excessive fruiting wood near the top of the bush, as required; 2 ) "speed" pruning involving removal of one or two of the most unproductive canes at the base of the bush; and 3) "un-pruned" where no pruning was done for the length of this study. Conventional pruning took an average of $6.4 \mathrm{~min} / \mathrm{plot}$, while speed pruning saved $88.8 \%$ time. There was no pruning treatment effect on the percentage of fruit buds in 'Berkeley' $(42 \%)$ or 'Bluecrop' $(34 \%)$ or percent fruit set $(70 \%$ to $90 \%$, depending on cultivar and year) in any year. Un-pruned plants of both cultivars had significantly greater yield than conventionally pruned plants, depending on the year, while speed pruning generally resulted in intermediate yields. Un-pruned and speed-pruned plants produced berries that were $19 \%$ to $27 \%$ smaller than conventionally pruned plants, depending on year. The fruit harvest season of un-pruned plants began 3 to 5 days later and lasted a week longer than that of conventionally pruned plants. The harvest efficiency of un-pruned plants was reduced as much as $\mathbf{5 1 \%}$ in the later years of this study and was most closely correlated with berry weight. Conventionally pruned plants had a significantly higher percentage of the above-ground dry weight allocated to 1-year-old wood and crown than un-pruned plants. In 'Bluecrop', $\mathbf{N}$ concentration tended to be higher in the crown of conventionally pruned plants than in un-pruned or speed-pruned plants. Conventionally pruned 'Bluecrop' plants had significantly higher concentrations of $K$ and $P$ and lower $N$ than un-pruned plants and 'Berkeley' had lower concentrations of $\mathrm{N}$, than un-pruned plants. Results indicate that not pruning mature plants may be an option in the short-term, but may have undesirable effects for long-term sustainability.
\end{abstract}

Blueberry plants are pruned to maintain consistent productivity and to increase berry weight (Brightwell and Johnston, 1944; Gough, 1994). Regular pruning allows more sunlight to penetrate the canopy which can improve flower bud formation and machine harvest efficiency (Gough, 1994). Removal of some flower buds during pruning can increase fruit set on the remaining buds and concentrate ripening (Mainland, 1989). Pruning also stimulates new cane growth (Seifker and Hancock, 1987).

In a 4-year study, increased pruning severity decreased yield, increased berry size, and slightly delayed maturation (Brightwell and

Received for publication 13 Apr. 2002. Accepted for publication 22 July 2002. We thank the Oregon Blueberry Commission and the Northwest Center for Small Fruits Research for supporting this research and Paula Stonerod and Gina Koskela for their technical assistance.

${ }^{1}$ Professor.

${ }^{2}$ Research Assistant, North Willamette Research and Extension Center.

${ }^{3}$ Associate Professor.
Johnston, 1944). Brightwell and Johnston's (1944) pruning recommendations included 1) removal of about one-third of the oldest canes annually and 2) reducing the number of fruit buds in cultivars that set heavily. They observed biennial bearing in plants that were Hancock (1987) studied the effect of pruning 15-year-old 'Jersey' that had never been pruned. Their pruning removed a percentage of the basal area of the plant in the first year with no pruning in subsequent years. Plants that remained un-pruned tended to biennially bear. Yield was only reduced when $40 \%$ of medium-sized canes at the base of the plant were removed. Almost all pruning severities were found to increase berry weight (Seifker and Hancock, 1987). In a comparison of three commercial plantings of 'Jersey', Hancock and Nelson (1985) observed that regular, moderate pruning (annual removal of $10 \%$ to $15 \%$ of the largest and weakest canes) produced the highest yields on the smallest number of canes.

The effect of pruning appears to be most related to cane age and number. Pritts and Han$\operatorname{cock}$ (1985) found that yield of un-pruned, wild not pruned or were pruned lightly. Siefker and blueberries increased until plants were $\approx 15$ to 20 years old at which point increases in cane number were offset by a decreased productivity per cane. In a comparison of nine blueberry cultivars, Siefker and Hancock (1986) found that in most cultivars, yield was more strongly determined by the number of canes per bush and berries per cane than berry number. As berry number per cane increased, berry weight was found to decrease.

In the Pacific Northwest, highbush blueberry plants are extremely vigorous and set many fruit buds. Plants are thus pruned annually for consistent production of high-quality fruit (Strik et al., 1993). The severity and method of pruning varies amongst growers with most making cuts at the base of the bush removing older canes and excessive 1-year-old "whip" growth, in addition to "top working" by removing a portion of the fruiting wood to prevent overproduction. Pruning is very labor intensive, accounting for about 30\% of the variable costs of maintaining a mature planting, not including harvesting costs (Lisec et al., 1993). Some growers "speed prune" by removing only a few older canes at the base of the plant with no top-working (Strik et al., 1990), thus saving labor costs.

The objectives of this study were to compare the effects of conventional, speed, and no pruning on pruning time, yield, berry weight, hand harvest efficiency, and dry weight partitioning in mature highbush blueberries.

\section{Materials and Methods}

This study was done on mature highbush blueberry plants established in Fall 1990 at the North Willamette Research and Extension Center, Aurora, Ore. Plants were spaced at 1.2 $\mathrm{m}$ in the row with $3 \mathrm{~m}$ between rows. The soil was a Quatama series (fine-loamy, mixed mesic Aqualtic Haploxeralfs). If rainfall was inadequate, irrigation was provided by overhead irrigation at a rate of $\approx 2.5$ to $3.8 \mathrm{~cm}$ per week during the growing season. Plants were maintained according to standard commercial practice for the location (Strik et al., 1993). Fertilizer was applied annually at a rate of $110 \mathrm{~N}-67 \mathrm{P}-67 \mathrm{~K} \mathrm{~kg}^{-h^{-1}}$ with $\mathrm{P}$ and $\mathrm{K}$ applied in the spring and $\mathrm{N}$ applied as a triple split (33\%: 33\%:33\%) in March, April and June.

The pruning treatments studied were: 1 ) "conventional" pruning - the industry standard practice consisting of removal of unproductive canes by cutting at the base of the bush or to productive new wood; thinning of new 1year-old shoots near the base of the bush; and removal of any unproductive wood or thinning of excessive fruiting wood near the top of the bush, as required (Strik et al., 1990, 1993); 2) "speed" pruning - removal of one or two of the most unproductive canes by cutting at the base of the bush; and 3) "un-pruned"- no pruning was done for the length of this study. Pruning treatments were initiated in winter $1995 / 96$. Prior to the initiation of this study, all bushes were pruned according to standard recommendations, "conventionally", from fall 1990 through Winter 1994/95 (Strik et al., 1990). 
Pruning treatments were conducted on the commercial cultivars Bluecrop and Berkeley. Each experimental unit (plot) consisted of three plants. The treatments were arranged in a factorial design with seven replicates of each experimental unit arranged in a completely random design. 'Berkeley' was studied from 1996 through 1998 with plants removed in winter 1998/99. 'Bluecrop' was studied from 1996 through 2000 with plants removed in Winter 2000/01. Although the pruning treatments were done in 1999, no yield related data were collected that year.

The time required to prune plots, 1-yearold lateral length, and the total number of buds and fruit buds per lateral (collected on a representative lateral from the apical, mid- and basal-section of the center bush per plot) were recorded each winter. During each growing season, data were collected on flower and berry number per lateral (percent fruit set calculated), yield, average berry weight ( 25 berry sub-sample), and time required to hand pick for each harvest date (in 1998 and 2000; only two harvest dates in 1996-97). Mean berry weight, total yield, percent yield by picking date, and picking efficiency $\left(\mathrm{g} \cdot \mathrm{min}^{-1} /\right.$ person) were calculated for each year of the study. Leaf tissue was collected in August of 1997 for nutrient analysis in both cultivars.

The center plant of each plot was removed at the end of the study and separated into 1-, 2-, 3-, 4-, and 5-year-old wood and crown tissues. Any dead wood was removed and not included. Roots were also not included. Dry weight of each tissue type was obtained after drying tissues at $70{ }^{\circ} \mathrm{C}$ in an oven until at constant weight. 'Berkeley' plants were removed in January, 1999 and 'Bluecrop' in January, 2001. In 'Bluecrop', a representative sub-sample of each tissue type was ground and analyzed for nutrient content.

Data were analyzed using the general linear model procedure of SAS (SAS Inst., 1990). Treatment means were compared using a protected least significant difference (LSD) test.

\section{Results and Discussion}

There was a significant effect of cultivar on pruning time only in 1996, when 'Bluecrop' required more time to prune $(5.4 \mathrm{~min} / \mathrm{plot}$ for conventional) than 'Berkeley' (4.2 min/plot; $P=0.036)$. There was no significant cultivar effect or cultivar $\times$ pruning treatment interaction from 1997-98. Conventional pruning took an average of $6.4 \mathrm{~min} /$ plot from 1996 to 2000 in 'Bluecrop', while speed pruning was $88.8 \%$ faster, requiring an average of $0.7 \mathrm{~min}$ per plot. Results were similar for 'Berkeley' (data not shown).

Pruning treatment or cultivar had no effect on internode length of 1-year-old laterals (averaged $1.2 \mathrm{~cm}$ ). 'Berkeley' had a higher percentage of fruit buds (averaged 42\%) than 'Bluecrop' (averaged 34\%) during the course of this study, but there was no pruning treatment effect in either cultivar. Even though insufficient pruning is thought to increase canopy density, thus decreasing light levels and flower bud initiation (Gough, 1994), we

Table 1. Effect of pruning method on yield per plot and mean berry weight of 'Bluecrop' and 'Berkeley' from 1996 to 2000 .

\begin{tabular}{|c|c|c|c|c|c|c|c|c|}
\hline \multirow[b]{2}{*}{ Treatment } & \multicolumn{4}{|c|}{ Total yield $\left(\mathrm{kg} \cdot \mathrm{plot}^{-1}\right)$} & \multicolumn{4}{|c|}{ Mean berry wt $(\mathrm{g})$} \\
\hline & 1996 & 1997 & 1998 & 2000 & 1996 & 1997 & 1998 & 2000 \\
\hline & \multicolumn{8}{|c|}{ Bluecrop } \\
\hline Conventional & $15.6 \mathrm{a}^{\mathrm{z}}$ & $15.5 \mathrm{a}$ & $19.2 \mathrm{a}$ & $21.7 \mathrm{a}$ & $1.6 \mathrm{a}$ & $2.2 \mathrm{a}$ & $2.1 \mathrm{a}$ & $1.9 \mathrm{a}$ \\
\hline Speed & $19.2 \mathrm{~b}$ & $26.9 \mathrm{~b}$ & $28.1 \mathrm{~b}$ & $23.1 \mathrm{a}$ & $1.5 \mathrm{a}$ & $1.7 \mathrm{~b}$ & $1.7 \mathrm{~b}$ & $1.4 \mathrm{~b}$ \\
\hline Un-pruned & $22.2 \mathrm{~b}$ & $29.3 \mathrm{~b}$ & $30.6 \mathrm{~b}$ & $31.1 \mathrm{~b}$ & $1.3 \mathrm{~b}$ & $1.6 \mathrm{~b}$ & $1.7 \mathrm{~b}$ & $1.5 \mathrm{~b}$ \\
\hline \multirow[t]{2}{*}{ Significance $^{z}$} & ** & $* * *$ & *** & $* *$ & $* * *$ & $* * *$ & $*$ & $* *$ \\
\hline & \multicolumn{8}{|c|}{ Berkeley } \\
\hline Conventional & $14.4 \mathrm{a}$ & $16.4 \mathrm{a}$ & $19.3 \mathrm{a}$ & --- & 2.2 & $2.5 \mathrm{a}$ & $2.6 \mathrm{a}$ & --- \\
\hline Speed & $17.7 \mathrm{ab}$ & $28.9 \mathrm{~b}$ & $25.1 \mathrm{a}$ & --- & 2.1 & $2.1 \mathrm{~b}$ & $2.3 \mathrm{a}$ & --- \\
\hline Un-pruned & $20.5 \mathrm{~b}$ & $33.1 \mathrm{~b}$ & $33.0 \mathrm{~b}$ & --- & 1.9 & $1.9 \mathrm{~b}$ & $1.8 \mathrm{~b}$ & --- \\
\hline Significance $^{2}$ & $*$ & $* * *$ & ** & --- & NS & $* * *$ & $* * *$ & --- \\
\hline
\end{tabular}

${ }^{2}$ Means followed by the same letter, within cultivar and year, are not significantly different by protected LSD, $P \geq 0.05$

Ns, ${ }^{*}, *, * * *$ Nonsignificant or significant at $P<0.05,0.01$, or 0.001 , respectively.
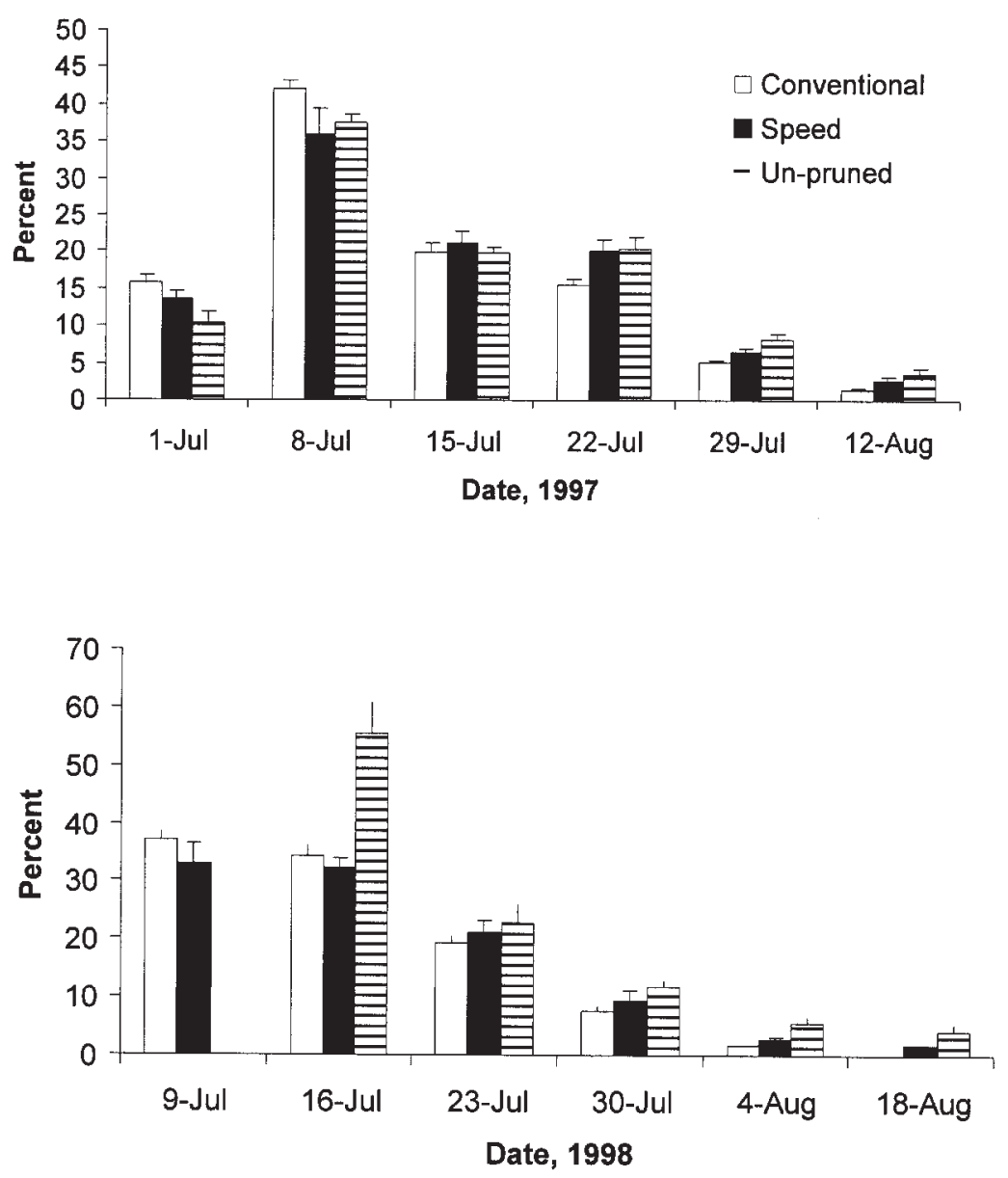

Fig. 1. Effect of pruning method on percent of total yield harvested on each picking date in 1997 and 1998 for 'Berkeley'.

saw little difference in canopy development, although light penetration was not measured. In both cultivars, speed and un-pruned plants had a spreading habit as older canes bent over; this may have improved light penetration to the center of the bush. Also, pruning treatment had no significant effect on percent fruit set of 'Bluecrop' (averaged 78\% to 90\%, depending on year) or 'Berkeley' ( $70 \%$ to $88 \%$ ).

There was no significant cultivar effect or treatment $\times$ cultivar interaction from 1996 to 1998 on yield. However, data are presented by cultivar in Table 1 , because an additional year's data were collected for 'Bluecrop'.
Pruning method significantly affected yield every year of this study, starting the first season after the treatments were imposed (Table 1). In 'Berkeley', un-pruned plants had from $42 \%$ to $102 \%$ greater yield than conventionally pruned plants. Speed pruning generally resulted in intermediate yields (Table 1). Yield of the conventionally pruned bushes increased over the 3-year study. However, in the un-pruned plants, yield in 1997 was similar to that in 1998 (Table 1).

In 'Bluecrop', un-pruned bushes produced $42 \%$ higher yield in the first year (Table 1). Although yield of the conventionally pruned 

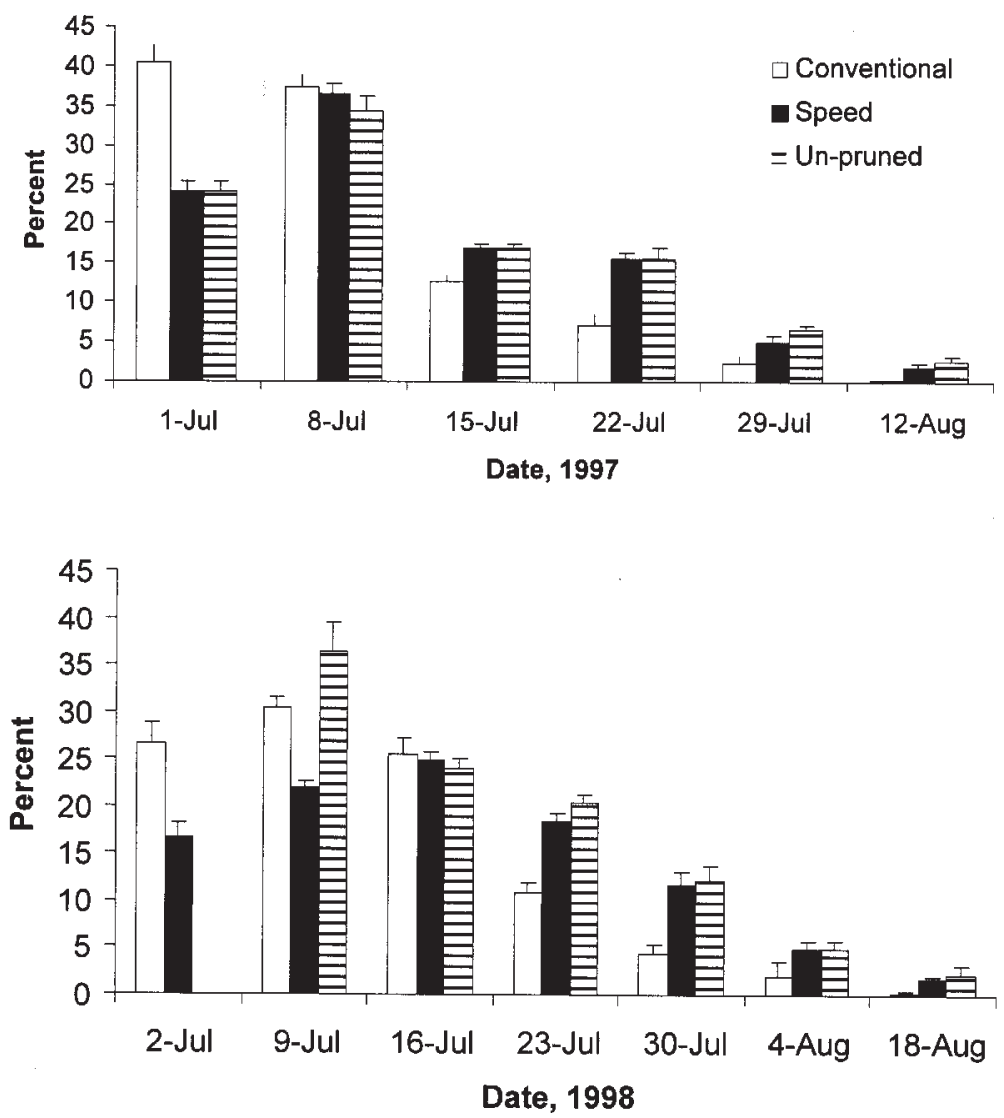

Fig. 2. Effect of pruning method on percent of total yield harvested on each picking date in 1997 and 1998 for 'Bluecrop'.

bushes was similar in years one and two, the un-pruned plants had a $32 \%$ greater yield in 1997 than in 1996. In contrast, un-pruned plants did not differ in yield from 1997 through 2000 , whereas yield of conventionally pruned plants increased during this same time period. Speed pruning produced inconsistent yields (Table 1). Thus, in contrast to other studies where un-pruned plants were biennially bearing (Brightwell and Johnston, 1944; Siefker and Hancock, 1987), un-pruned plants in this study consistently had the highest yield over a 3- to 5 -year period. Our results may be different from previous studies because, plants were pruned annually before this study was initiated, our conventional pruning treatment is relatively severe, and perhaps due to cultivar differences.

The fruit harvest season was advanced by pruning, particularly in the conventionally pruned plants. In 1996, 50\% and $95 \%$ of the total yield of 'Bluecrop' was harvested 3 and $5 \mathrm{~d}$ later in un-pruned plants compared to conventionally pruned plants, respectively $(P$ $<0.001 ; P<0.05)$. In 'Berkeley', there was no pruning effect on harvest season in 1996 (data not shown). However, in 1997 and 1998, un-pruned 'Berkeley' and 'Bluecrop' plants had a significantly lower percentage of yield picked on the first harvest and more on the last harvest (Figs. 1 and 2). In 1998, plants that had not been pruned for 3 years had no ripe fruit on the first harvest, when the conventionally pruned bushes averaged $27 \%$ and $37 \%$ of total yield for 'Berkeley' and 'Bluecrop', respectively (Figs. 1 and 2). Speed pruned plants had intermediate yields (Table 1) and the harvest season was not as delayed as in the un-pruned plants (Figs. 1 and 2). Gough (1983) found that un-pruned 'Bluecrop' plants flowered from 0 to 5 d earlier than pruned plants. Although we did not record bloom date in this study, our results seem to mirror his, as the harvest season of unpruned plants started $\approx 3$ to $5 \mathrm{~d}$ later and was a week longer than that of the conventionally pruned plants. Heavy pruning was also found to advance the fruiting season of 'Rubel' and 'Pioneer' (Brightwell and Johnston, 1944).

Average berry weight was significantly affected by pruning method in all years for 'Bluecrop', with un-pruned plants having from $19 \%$ to $27 \%$ smaller berries than conventionally pruned plants, depending on year (Table 1). Berry weight in speed-pruned plants was not significantly different from un-pruned plants in all years except 1996 (Table 1). Total yield was negatively correlated with berry weight in 'Bluecrop' in $1998(r=-0.532 ; P=0.0004)$, but not in 2000 . Berry weight varied throughout the harvest season for all treatments and cultivars. In 1998, for example, the largest fruit were harvested on the second picking date (Fig. 3). Most of the pruning treatment effects on berry weight occurred from the third picking date to the end of the season (Fig. 3). In 'Berkeley', there was no pruning treatment effect on berry weight in 1996 (Table 1). However, in 1997 and 1998, un-pruned plants had 24\% and $23 \%$ smaller berries than conventionally pruned plants, respectively.

Average picking efficiency was not affected by pruning treatment in 1996-98 in 'Bluecrop' (Table 2). However, in 2000, average picking efficiency was $51 \%$ higher in conventionally pruned plants than in un-pruned plants. Picking efficiency of speed-pruned plants was not significantly different from un-pruned plants in 2000 (Table 2). Average picking efficiency was correlated with average berry weight in $1998(r$ $=0.613 ; P=0.0001)$ and $2000(r=0.872 ; P=$ $0.0001)$. Thus, conventional pruning increased the weight of fruit that could be harvested per hour, thus reducing hand-picking costs.

Although, we did not measure machine harvest efficiency, observations suggest that there would likely have been a treatment effect. Un-pruned and speed-pruned plants had poor plant architecture (drooping habit and dense) and dead wood that would likely break off during machine harvest, especially by the third year of this study.

In 1997, tissue analyses after fruit harvest (August) showed that conventionally pruned 'Bluecrop' plants had significantly higher foliar concentrations of $\mathrm{K}$ and $\mathrm{P}$ and lower concentrations of $\mathrm{N}$, calcium $(\mathrm{Ca})$, magnesium $(\mathrm{Mg})$, manganese $(\mathrm{Mn})$, copper $(\mathrm{Cu})$, and boron (B) than speed- or un-pruned plants (data not shown). In 'Berkeley', there was no pruning treatment effect on $\mathrm{P}, \mathrm{K}, \mathrm{Mn}, \mathrm{Cu}$, or $\mathrm{B}$, but concentrations of $\mathrm{N}, \mathrm{Ca}$, and $\mathrm{Mg}$ were lower in conventionally pruned plants that in speed- or un-pruned plants (data not shown). Ballinger and Kushman (1966) found that high-yielding plants had a higher percentage of leaf tissue $\mathrm{N}$ than plants with a lower yield. However, they found no effect of crop load on leaf tissue levels of $\mathrm{P}, \mathrm{K}, \mathrm{Ca}$, and $\mathrm{Mg}$, although the percentage of $\mathrm{P}, \mathrm{K}$, and $\mathrm{Mg}$ was higher in the fruit of heavily cropped plants. In our study, the heavily cropped un-pruned plants, may have had more $\mathrm{P}$ and $\mathrm{K}$ in the fruit and thus lower leaf tissue levels. Nutrients such as $\mathrm{N}$ may have been more concentrated in leaves, because the un-pruned plants grew slower than the more lightly cropped conventionally pruned plants.

At the end of this study, 'Bluecrop' plants that were conventionally pruned had significantly more dry weight of 1 -year-old wood than speed pruned plants and plants not pruned for 6 years (Table 3). Conventionally pruned plants also had a higher dry weight of 2-year-old wood, crown, and total above-ground tissues than speed pruned plants (Table 3). Conventionally pruned plants had a significantly higher percentage of the aboveground dry weight allocated to 1-year-old wood $(9.5 \% ; P=0.0001)$ and crown $(26.1 \%$; $P=0.0059)$ than un-pruned plants $(6.3 \%$ and $20.7 \%$, respectively). In contrast, un-pruned plants tended to have a greater percentage of dry weight in older wood tissues ( $>2$-year-old; $P=0.0001)$. There was little effect of pruning treatment on the dry weight of above-ground wood in 'Berkeley' following 3 years of pruning treatments (Table 3). However, the effect of pruning treatment on the percentage of dry weight allocated to the different wood ages 


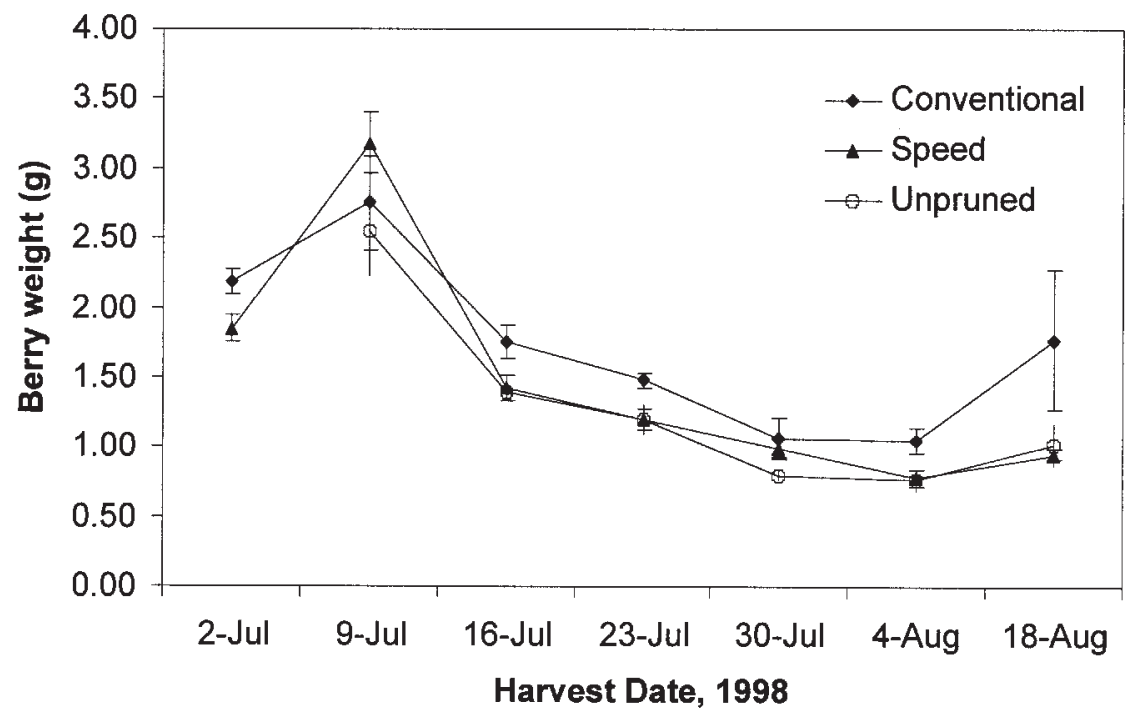

Fig. 3. Effect of pruning method on average berry weight of 'Bluecrop' by picking date in 1998 .

Table 2. Effect of pruning method on hand picking efficiency of 'Bluecrop' and 'Berkeley' from 1997 to 2000.

\begin{tabular}{lccc}
\hline & \multicolumn{3}{c}{ Picking efficiency $\left(\mathrm{g} \cdot \mathrm{min}^{-1} /\right.$ person $)$} \\
\cline { 2 - 4 } Treatment & $1997^{\mathrm{z}}$ & $1998^{\mathrm{z}}$ & $2000^{\mathrm{z}}$ \\
\hline Conventional & 147.1 & Bluecrop & \\
Speed & 122.9 & 61.0 & $130.4 \mathrm{a}^{\mathrm{y}}$ \\
Un-pruned & 96.2 & 54.8 & $87.0 \mathrm{~b}$ \\
Significance $^{y}$ & $\mathrm{NS}$ & 57.8 & $86.4 \mathrm{~b}$ \\
& & NS & $* * *$ \\
Conventional & 102.9 & Berkeley & \\
Speed & 135.3 & $83.9 \mathrm{a}$ & --- \\
Un-pruned & 106.0 & $68.0 \mathrm{~b}$ & -- \\
Significance $^{y}$ & NS & $62.3 \mathrm{~b}$ & -- \\
\hline
\end{tabular}

${ }^{2}$ Picking efficiencies are an average of the first and second harvest in 1997, all seven harvests in 1998, and all three harvests in 2000.

${ }^{y}$ Means followed by the same letter, within cultivar and year, are not significantly different by protected LSD, $P \geq 0.05$.

ss, ${ }^{*}, * * * * * *$ Nonsignificant or significant at $P<0.05,0.01$, or 0.001 , respectively.

Table 3. Effect of pruning method on dry weight partitioning of aboveground plant parts by wood age of 'Bluecrop' (winter 2001) and 'Berkeley' (winter 1999).

\begin{tabular}{|c|c|c|c|c|c|c|c|}
\hline \multirow[b]{2}{*}{ Treatment } & \multicolumn{7}{|c|}{ Dry wt (kg/plant part) } \\
\hline & 1-year & 2-year & 3 -year & 4-year & 5-year & Crown & $\begin{array}{c}\text { Total } \\
\text { above-ground }\end{array}$ \\
\hline \multicolumn{8}{|c|}{ Bluecrop } \\
\hline Conventional & $0.50 \mathrm{a}^{\mathrm{z}}$ & $0.61 \mathrm{a}$ & 0.52 & $0.66 \mathrm{ab}$ & $1.57 \mathrm{ab}$ & $1.37 \mathrm{a}$ & $5.22 \mathrm{a}$ \\
\hline Speed & $0.32 \mathrm{~b}$ & $0.40 \mathrm{~b}$ & 0.47 & $0.50 \mathrm{~b}$ & $1.08 \mathrm{~b}$ & $0.92 \mathrm{~b}$ & $3.69 \mathrm{~b}$ \\
\hline Un-pruned & $0.35 \mathrm{~b}$ & $0.55 \mathrm{ab}$ & 0.67 & $0.81 \mathrm{a}$ & $1.96 \mathrm{a}$ & $1.14 \mathrm{ab}$ & $5.48 \mathrm{a}$ \\
\hline Significance $^{z}$ & ** & $*$ & NS & $*$ & ** & $*$ & $*$ \\
\hline \multicolumn{8}{|c|}{ Berkeley } \\
\hline Conventional & 0.38 & 0.36 & $0.51 \mathrm{a}$ & 0.68 & 0.83 & 2.85 & 5.60 \\
\hline Speed & 0.37 & 0.49 & $0.61 \mathrm{ab}$ & 0.83 & 0.92 & 2.90 & 6.11 \\
\hline Un-pruned & 0.37 & 0.46 & $0.85 \mathrm{~b}$ & 1.13 & 1.21 & 2.77 & 6.79 \\
\hline Significance $^{2}$ & NS & NS & * & NS & NS & NS & NS \\
\hline
\end{tabular}

${ }^{2}$ Means followed by the same letter, within cultivar, are not significantly different by protected LSD, $P \geq$ 0.05 by wood age.

Ns, ${ }^{*, * *, * * *}$ Nonsignificant or significant at $P<0.05,0.01$, or 0.001 , respectively.

in 'Berkeley' was similar to that observed in 'Bluecrop'.

In 'Bluecrop', nitrogen $(\mathrm{N})$ concentration tended to be higher in the crown of conventionally pruned plants $(0.63 \%)$ than in un-pruned or speed-pruned plants $(0.47 \%$ and $0.46 \%$, respectively). Perhaps, along with the lower dry weight (Table 3 ), this was an indication of lower reserve $\mathrm{N}$ in un-pruned plants. Note, however, that we did not collect root data in this

study, another major source of stored reserves. In addition, there was a significantly higher concentration of $\mathrm{N}$ in 1-, 2-, and 4-year-old wood from speed and un-pruned plants as compared to conventionally pruned plants (data not shown), perhaps due to heavy cropping or a reduced growth rate.

In conclusion, the data indicate that there is little negative effect on berry weight, yield, or picking efficiency of not pruning mature
'Bluecrop' or 'Berkeley' for one season. In fact, un-pruned plants produced a higher yield with a similar picking efficiency to conventionally pruned bushes with considerable savings in labor costs. However, in bushes left un-pruned for 2 to 5 years berry weights were significantly smaller, picking efficiency was reduced by as much as $50 \%$, and less renewal wood was produced. Un-pruned plants also had a later fruiting season, which could be significant for fresh market growers. Results thus indicate that although not pruning may be an alternative in the short-term, it is not a sustainable option for long-term production due to relatively low partitioning of resources to 1-year-old wood, lower $\mathrm{N}$ reserves in the crown tissue, and poor plant architecture.

The method of speed pruning that we used did not seem a good alternative for Oregon growers. Although speed pruning saved 89\% labor compared to conventional pruning, yields were inconsistent and speed pruning had little impact on berry weight and season. Although the oldest one or two canes were removed per plant when speed pruning, it became apparent toward the end of the study that the number of canes removed needed to be higher to remove a sufficient quantity of unproductive or dead wood. The picking efficiency of speed-pruned plants was low, because the berry weight of speed pruned plants was similar to that of unpruned plants.

\section{Literature Cited}

Ballinger, W.E. and L.J. Kushman. 1966. Factors affecting the mineral-element content of leaves and fruit of Wolcott blueberries. Proc. Amer. Soc. Hort. Sci. 88:325-330.

Brightwell, W.T. and S. Johnston. 1944. Pruning the highbush blueberry. Michigan State Coll. Tech. Bul. 192.

Gough, R.E. 1983. Time of pruning and bloom date in cultivated highbush blueberry. HortScience 18: 934-935.

Gough, R.E. 1994. The highbush blueberry and its management. Food Products Press, New York. 137-149.

Hancock, J.F. and J.W. Nelson. 1985. Factors influencing yields of Vaccinium corymbosum L. in Michigan. Acta Hort. 165:107-113.

Lisec, B., T. Cross, and B. Strik. 1993. Blueberry economics. The costs of establishing and producing blueberries in the Willamette Valley. Oregon State Univ. Ext. Serv. Publ., EM 8526, Corvallis.

Mainland, C.M. 1989. Pruning. Proc. of the $23^{\text {rd }}$ Annu. Open House, Southeastern Blueberry Council. Elizabethtown, N.C.: North Carolina State Univ. $10-16$.

Pritts, M.P. and J.F. Hancock. 1985. Lifetime biomass partitioning and yield component relationships in the highbush blueberry, Vaccinium corymbosum (Ericaceae). Amer. J. Bot. 72:446-452.

SAS Institute. (1990). SAS/STAT user's guide: Statistics, Version 6, 4th ed. SAS Inst., Cary, NC.

Seifker, J.A. and J.F. Hancock. 1986. Yield component interactions in cultivars of the highbush blueberry. J. Amer. Soc. Hort. Sci. 111:606-608.

Seifker, J.A. and J.F. Hancock. 1987. Pruning effects on productivity and vegetative growth in the highbush blueberry. HortScience 22:210-211.

Strik, B., D. Brazelton, and R. Penhallegon. 1990. Grower's Guide to Pruning Highbush Blueberries. Oregon State Univ. Ext. Serv. Video, VTP002, Corvallis.

Strik, B., C. Brun, M. Ahmedullah, A. Antonelli, L. Askham, D. Barney, P. Bristow, G. Fisher, J. Hart, D. Havens, R. Ingham, D. Kaufman, R. Penhallegon, J. Pscheidt, B. Scheer, C. Shanks, and R. William. 1993. Highbush blueberry production. Oregon State Univ. Ext. Serv. Publ., PNW215, Corvallis. 